\title{
Hubungan Kejadian Fibrilasi Atrium dengan Diameter Atrium Kiri pada Fibrilasi Atrium Valvular dan Fibrilasi Atrium Non-Valvular Di RSUD Arifin Achmad
}

\author{
Sri adeyana ${ }^{1}$, Haryadi² ${ }^{2}$ Chandra Wijaya ${ }^{2 *}$
}

\begin{abstract}
Atrial Fibrillationis a kind of arrhythmia which has the most incidence. Based on its Etiology, atrial fibrillationcould be divided in to two, valvular and nonvalvular atrial fibrillation. This study was aimed toknow the correlation of atrial fibrillation incidence between valvular and nonvalvular with its left atrium diameter in Arifin Achmad Provinsi Riau's General Hospital. This study was analytical and done by cross sectional approach with 185 patient. The data were processing with computerize to univariate analysis and chi-square for bivarite analysis. From this study it can be concluded that the most occurrence of atrial fibrillation was non valvular atrial fibrillation which was $76,8 \%$ with the etiology mostly of hypertension which was $41,5 \%$. Valvular atrial fibrillation was mostly caused by mitral stenosis which was $37,2 \%$ and there were no correlation between the diameter of left atrium to the occurrence of valvular and non valvular atrial fibrillation $(\mathrm{p}=0,273$.
\end{abstract}

Keywords: Atrial fibrillation, valvular, non valvular

Fibrilasi atrium merupakan aritmia yang paling sering terjadi. Insidensinya di negara berkembang di antara akhir abad ke-20 dan awal abad ke-21 menunjukkan peningkatan menjadi $0,5 \%$ dan $1 \%{ }^{1}$ Prevalensi fibrilasi atrium di Amerika dan Eropa Barat menunjukkan terjadi peningkatan angka fibrilasi atrium pada 20 tahun terakhir dari 2,7-6,1 juta meningkat menjadi 5,6-12,1 juta. ${ }^{2,3}$ Di Indonesia masih belum ada data terkait prevalensi fibrilasi atrium, namun di Rumah Sakit Jantung dan Pembuluh Darah Harapan Kita menunjukkan terjadi peningkatan pasien yang dirawat dengan fibrilasi atrium setiap tahunnya, yaitu 7,1\% (2010), 9,0\% (2011), 9,3\% (2012) dan 9,8\% (2013). ${ }^{4}$

Fibrilasi atrium dipicu oleh berbagai penyakit kardiovaskular atau selain penyakit kardiovaskular. Risiko terkait fibrilasi atrium seperti usia, jenis kelamin, hipertensi, penyakit katup jantung, gagal jantung, diabetes, penyakit arteri koroner, obesitas,

\footnotetext{
* Korespondensi: cdrwjy@ gmail.com

1 Fakultas Kedokteran Universitas Riau

2 KJF Ilmu Penyakit Jantung Fakultas Kedokteran Universitas Riau - RSUD Arifin Achmad Provinsi Riau
}

disfungsi tiroid, penyakit ginjal kronik, alkohol dan merokok, genetik, dan aktifitas. Risiko ini dapat memicu terjadinya fibrilasi atrium melalui proses remodeling atrium kiri seperti jaringan parut di atrium, konduksi yang heterogen, fibrosis atrium dan disfungsi irama jantung. ${ }^{5,6}$

Penyebab fibrilasi atrium dibagi menjadi dua, yaitu fibrilasi atrium dengan kelainan katup (valvular) dan tanpa kelainan katup jantung (nonvalvular). Fibrilasi atrium dengan kelainan katup adalah fibrilasi atrium yang diakibatkan oleh penyakit jantung rematik terutama mitral stenosis atau katup jantung prostetik, sedangkan fibrilasi atrium tanpa kelainan katup jantung adalah fibrilasi atrium yang bukan disebabkan oleh penyakit jantung rematik katup prostetik atau perbaikan katup jantung. ${ }^{7,8}$ Insidensi fibrilasi atrium tanpa kelainan katup jantung lebih banyak dibandingkan fibrilasi atrium dengan kelainan katup jantung. Penelitian terkini menunjukkan kejadian fibrilasi atrium dengan kelainan katup jantung sebanyak $10,1 \%$ dan fibrilasi atrium tanpa kelainan katup jantung adalah $89,7 \% .^{9}$ 


\section{METODE}

Desain penelitian ini adalah analitik dengan pendekatan cross-sectional mengenai hubungan kejadian fibrilasi atrium dengan kelainan katup jantung dan tanpa kelainan katup jantung dengan diameter atrium kiri di RSUD Arifin Achmad provinsi Riau. Penelitian ini telah dilakukan di RSUD Arifin Achmad provinsi Riau dan berlangsung pada bulan April 2016- Mei 2017.

Populasi penelitian ini adalah seluruh pasien fibrilasi atrium yang berada di instalasi jantung RSUD Arifin Achmad provinsi Riau. Teknik pengambila sampel menggunakan teknik konsekutif sampling dengan sampel minimal 150 sampel.

\section{HASIL}

\section{Karakteristik Responden}

Pada tabel 1, didapatkan distribusi frekuensi fibrilasi atrium berdasarkan usia. Fibrilasi atrium lebih banyak terjadi pada laki-laki yaitu 110 pasien $(59,5 \%)$. Distribusi frekuensi fibrilasi atrium berdasarkan usia paling banyak terjadi pada usia 5160 tahun yaitu 60 pasien $(32,4 \%)$ dan paling sedikit pada usia $\leq 20$ dan 21-30 tahun dengan hasil yang sama yaitu masing-masing 4 pasien $(2,2 \%)$.

Tabel 1 Distribusi Frekuensi Karakteristik pasien

\begin{tabular}{cll}
\hline Karakteristik & Frekuensi & Persentase (\%) \\
\hline Jenis Kelamin & 110 & $59,5 \%$ \\
Laki-laki & 75 & $40,5 \%$ \\
Perempuan & & \\
Usia (tahun) & 4 & $2,2 \%$ \\
$\leq 20$ & 4 & $2,2 \%$ \\
$21-30$ & 11 & $5,9 \%$ \\
$31-40$ & 37 & $20 \%$ \\
$41-50$ & 60 & $32,4 \%$ \\
$51-60$ & 46 & $24,9 \%$ \\
$61-70$ & 23 & $12,4 \%$ \\
$? 71$ & 185 & $100 \%$ \\
\hline Jumlah & &
\end{tabular}

\section{Distribusi Frekuensi Fibrilasi Atrium dengan Kelainan Katup (valvular) dan Tanpa Kelainan Katup Jantung (nonvalvular)}

Distribusi frekuensi berdasarkan penyebabnya pasien fibrilasi atrium tanpa kelainan katup jantung (nonvalvular) lebih banyak dibandingkan dengan pasien fibrilasi atrium dengan kelainan katup jantung (valvular). Hasil penelitian didapatkan fibrilasi atrium tanpa kelainan katup jantung yaitu 142 pasien $(76,8 \%)$ dan fibrilasi atrium dengan kelainan katup jantung yaitu 43 pasien $(23,3 \%)$. Distribusi berdasarkan penyebab fibrilasi atrium terdapat pada tabel 2 .

Tabel 2 Distribusi frekuensi fibrilasi atrium valvular dan nonvalvular

\begin{tabular}{lll}
\hline Penyebab fibrilasi atrium & Jumlah & Persentase (\%) \\
\hline Valvular & 43 & $23,2 \%$ \\
Nonvalvular & 142 & $76,8 \%$ \\
\hline Jumlah & 185 & $100 \%$ \\
\hline
\end{tabular}

\section{Distribusi Frekuensi Kelainan pada Fibrilasi Atrium Valvular dan Nonvavular}

Fibrilasi atrium tanpa kelainan katup jantung paling banyak disebabkan oleh hipertensi yaitu 59 pasien $(41,5 \%)$. Setelah hipertensi, penyakit yang paling sering kedua penyebab fibrilasi atrium adalah gagal jantung yaitu 50 pasien $(35,2 \%)$. Penyakit penyakit lain yang menyebabkan fibrilasi atrium 
Sri Adeyana, dkk, Hubungan Kejadian Fibrilasi Atrium

seperti penyakit jantung koroner $(11,3 \%)$, diabetes mellitus $(6,3 \%)$, gagal ginjal kronik $(1,4 \%)$.
Penyakit lain-lain adalah hipertiroid 4,2\%. Distribusi frekuensi kelainan fibrilasi atrium tanpa kelainan katup jantung (nonvalvular) pada tabel 3.

Tabel 3 Penyebab fibrilasi atrium tanpa kelainan katup jantung (nonvalvular)

\begin{tabular}{lll}
\hline Penyebab fibrilasi atrium nonvalvular & Jumlah & Persentase (\%) \\
\hline Hipertensi & 59 & $41,5 \%$ \\
Diabetes mellitus & 9 & $6,3 \%$ \\
Gagal jantung & 50 & $35,2 \%$ \\
Gagal ginjal kronik & 2 & $1,4 \%$ \\
Penyakit jantung koroner & 16 & $11,3 \%$ \\
Lainnya & 6 & $4,2 \%$ \\
\hline Jumlah & 142 & $100 \%$ \\
\hline
\end{tabular}

Fibrilasi atrium dengan kelainan katup jantung paling sering disebabkan oleh stenosis mitral yaitu 16 pasien $(37,2 \%)$. Selain stenosis mital kelainan katup yang sering menyebabkan fibrilasi atrium adalah pemakaian katup prostetik. Kelainan lainlain merupakan persentase paling yaitu 1 pasien $(2,3 \%)$. Distribusi frekuensi kelainan fibrilasi atrium dengan kelainan katup (valvular) pada tabel 4.

Tabel 4 Penyebab fibrilasi atrium dengan kelainan katup jantung (valvular)

\begin{tabular}{lll}
\hline Penyebab fibrilasi atrium valvular & Jumlah & Persentase (\%) \\
\hline Stenosis mitral & 16 & $37,2 \%$ \\
Regurgitasi mitral & 11 & $25,6 \%$ \\
Pemakaian katup prostetik & 15 & $34,9 \%$ \\
Katup lainnya & 1 & $2,3 \%$ \\
\hline Jumlah & 43 & $100 \%$ \\
\hline
\end{tabular}

Hubungan antara Kejadian Fibrilasi Atrium pada Kelainan Katup (valvular) dan tanpa Kelainan Katup Jantung (nonvalvular) dengan Diameter Atrium Kiri

Berdasarkan hasil uji chi square diperoleh nilai $p=0,273(p>0,05)$, sehingga dapat disimpulkan bahwa tidak terdapat hubungan antara kejadian fibrilasi atrium dengan kelainan katup dan tanpa kelainan katup dengan diameter atrium kiri di RSUD Arifin Achmad Provinsi Riau. Tabel 4 menunjukkan hasil bahwa pasien fibrilasi atrium dengan kelainan katup yang memiliki diameter atrium kiri $\leq 40 \mathrm{~mm}$ yaitu $25,6 \%$ dan pasien fibrilasi atrium dengan kelainan katup yang memiliki diameter atrium kiri $>40 \mathrm{~mm}$ yaitu $74,4 \%$. Pasien fibrilasi atrium tanpa kelainan katup yang memiliki diameter atrium kiri $\leq 40 \mathrm{~mm}$ yaitu $34,5 \%$ dan pasien fibrilasi atrium yang memiliki diameter atrium kiri $>40 \mathrm{~mm}$ yaitu $65,5 \%$. Hasil analisis dengan uji chi square pada tabel 5.

Tabel 5 Analisis hubungan antara kejadian fibrilasi atrium pada kelainan katup dan tanpa kelainan katup jantung di RSUD Arifin Achmad Provinsi Riau

\begin{tabular}{llllll}
\hline penyebab & \multicolumn{2}{l}{ Diameter atrium kiri } & P value \\
\cline { 2 - 5 } & $\leq 40 \mathrm{~mm}$ & \multicolumn{3}{c}{$\mathrm{n}$ mm } & \\
\cline { 2 - 5 } & $\mathrm{n}$ & $\%$ & $\mathrm{n}$ & $\%, 273$ \\
Valvular & 11 & $25,6 \%$ & 32 & $74,4 \%$ & 0,273 \\
nonvalvular & 49 & $34,5 \%$ & 93 & $65,5 \%$ & \\
\hline
\end{tabular}




\section{PEMBAHASAN}

\section{Karakteristik Pasien}

Fibrilasi atrium lebih banyak terjadi pada pria dibandingkan wanita yaitu 110 pasien $(59,5 \%)$. Hasil penelitian ini relatif sama dengan hasil yang didapatkan oleh Chugh SS dkk (2010) yaitu 33,5 juta terjadi pada laki-laki dan 12,6 juta pada perempuan dan penelitian Berisso MZ dkk (2014) di Eropa yaitu laki-laki banding perempuan adalah 1,2:1. ${ }^{10,11}$ Penelitian oleh Friberg L dkk (2013) di Swedia, dari 209. 141 orang yang didiagnosis fibrilasi atrium, sebanyak 55\% terjadi pada lakilaki. $^{12}$

Fibrilasi atrium umumnya lebih tinggi pada laki-laki dibandingkan perempuan disebabkan karena laki-laki memiliki ekspresi repolarisasi kanal ion berlebih, yang dapat mempercepat repolarisasi atrium, pemendekan periode refrakter atrium dan mekanisme keluar masuk ion. Selain itu, laki-laki memiliki diameter atrium kiri lebih besar dibandingkan diameter atrium kiri wanita, sehingga risiko fibrilasi atrium cenderung lebih tinggi pada laki-laki. ${ }^{13}$

Insidensi fibrilasi atrium meningkat dengan bertambahnya usia. Hasil penelitian ini didapatkan usia pasien fibrilasi atrium paling banyak terjadi pada rentang usia 51-60 tahun yaitu 32,4\% dan 6170 tahun yaitu $24,9 \%$. Penelitian ini sama dengan penelitian Ayed SD dkk (2012) yaitu rata-rata usia fibrilasi atrium terjadi pada usia $68 \pm 12$ tahun. ${ }^{14}$ Penelitian oleh Rao DV dkk (2014) di rumah sakit jantung Mamata selama satu tahun paling banyak terjadi pada usia 50-60 tahun yaitu 32,65\%. ${ }^{15}$ Penelitian Berisso MZ dkk (2013) menunjukkan fibrilasi atrium paling banyak terjadi pada usia lebih dari 80 tahun yaitu $10-17 \% .^{10,11}$ Perbedaan hasil penelitian ini disebabkan kunjungan rumah sakit tertinggi pada usia 51-60 tahun, selain itu usia harapan hidup penduduk Riau tidak lebih dari 70 tahun, sehingga peningkatan usia sebagai risiko fibrilasi atrium tidak tergambar. ${ }^{16}$ Usia merupakan faktor pemicu terbesar pada fibrilasi atrium. Peningkatan usia memicu terjadinya remodelling dan dilatasi. Atrofi otot atrium dapat mengganggu konduksi dan kontraksi di atrium sehingga semakin memperburuk kondisi atrium. Peningkatan usia lebih berisiko menjadi fibrilasi atrium melalui penyakit kardiovaskular lain, seperti hipertensi, penyakit arteri koroner, gangguan katup jantung, dan gagal jantung. ${ }^{17}$

\section{Fibrilasi Atrium dengan Kelainan Katup (valvular) dan tanpa Kelainan Katup Jantung (nonvalvular)}

Penyebab fibrilasi atrium dibagi menjadi dua, yaitu fibrilasi atrium dengan kelainan katup (valvular) dan tanpa kelainan katup jantung (nonvalvular).Fibrilasi atrium valvular adalah fibrilasi atrium yang diakibatkan oleh penyakit jantung rematik terutama mitral stenosis atau katup jantung prostetik, sedangkan fibrilasi atrium nonvalvular adalah fibrilasi atrium yang bukan disebabkan oleh penyakit jantung rematik katup prostetik atau perbaikan katup jantung. ${ }^{7,8}$

Hasil penelitian didapatkan pasien fibrilasi atrium paling bayak merupakan fibrilasi atrium nonvalvular yaitu $76,8 \%$ dan fibrilasi atrium valvular sebanyak $23,3 \%$. Penelitian ini relatif sama dengan penelitian Philippart R (2015) didapatkan fibrilasi atrium yang lebih banyak terjadi adalah fibrilasi atrium nonvalvular yaitu $89,7 \% .{ }^{9} \mathrm{Hal}$ ini disebabkan karena prevalensi gangguan katup lebih kecil dibandingkan kejadian penyakit kardiovaskular lain yang menyebabkan fibrilasi atrium nonvalvular seperti hipertensi, diabetes, gagal jantung dan lain-lain. Keadaan ini memicu perubahan struktur dari jantung dari tingkat seluler berupa remodelling terutama fibrosis. ${ }^{17}$

Fibrosis merupakan faktor utama terjadinya dilatasi atrium. Dilatasi atrium dapat mengakibatkan abnormalitas hampir pada keseluruhan jantung yang menyebabkan peningkatan tekanan di dalam jantung. Dilatasi atrium memicu aktivasi sistem renin angiotensin aldosteron yang selanjutnya meningkatkan pengendapan dari matriks metalloproteinase dan disintegrin pada dinding atrium. Sistem renin angiostensin aldosteron nantinya akan menginisiasi sel-sel untuk mengirimkan sinyal agar meningkatkan kalsium intrasel, apoptosis, lepasnya sitokin dan inflamasi, oksidative stress, dan produksi growth-related factor yang juga menstimulasi fibrosis. Angiotensin II, angiotensin converting enzym (ACE) dan aldosteron merupakan komponen-komponen sistem renin angiotensin aldosteron yang disintesis pada 
miokardium atrium dan meningkat selama fibrilasi atrium. Keadaan ini memicu proses remodelling atrium dan fibrosis melalui hilangnya massa otot atrium. ${ }^{17}$

Penyebab fibrilasi atrium nonvalvular paling banyak disebabkan oleh hipertensi. Penelitian ini sesuai dengan teori yaitu $41,5 \%$ pasien fibrilasi adalah pasien hipertensi. Penelitian ini sama dengan penelitian Friberg L dkk (2013) yaitu pasien fibrilasi atrium adalah pasien hipertensi yaitu $45 \% .{ }^{12}$ Penelitian Ertas Faruk dkk (2013) didapatkan hasil fibrilasi atrium yang terjadi sebanyak $65 \%$ menderita hipertensi. ${ }^{18}$ Fibrilasi atrium terbanyak setelah hipertensi di RSUD Arifin Achmad provinsi Riau adalah gagal jantung yaitu $35,2 \%$. Hasil penelitian ini sesuai dengan penelitian Ertas F dkk (2013) di Turki pada 2242 pasien fibrilasi atrium yaitu $28,6 \% .{ }^{18}$ Penelitian Friberg L dkk (2013) juga menunjukkan bahwa gagal jantung merupakan peringkat kedua penyebab fibrilasi atrium yaitu $31 \% .^{12}$

Hipertensi merupakan penyakit komorbid yang sering terjadi pada fibrilasi atrium. Hipertensi dalam jangka waktu lama akan berkembang menjadi hipertrofi ventrikel kiri yang merupakan tanda klinis yang sangat penting dari kerusakan organ dan faktor risiko penyakit kardiovaskular lain termasuk fibrilasi atrium. pada hipertrofi ventrikel kiri pemenuhan ventrikel kiri menurun, ventrikel kiri menjadi kaku dan tekanan pengisian meningkat, cadangan aliran arteri koroner menurun, ketegangan dinding meningkat dan peningkatan aktivasi sistem saraf simpatis dan sistem renin angiostensin aldosteron. Sel dan struktur atrium berubah dari fibroblas menjadi miofibroblas dan meningkatkan deposit dan fibrosis sebagai tanda dari proses remodelling.Remodelling mengakibatkan pemisahan kelistrikan antara ikatan otot dan konduksi lokal heterogen yang memulai fibrilasi atrium. Remodelling dalam jangka waktu yang lama akan meningkatkan dan mempertahankan fibrilasi atrium melalui perubahan dari struktur atrium. ${ }^{17}$

Gagal jantung dapat meningkatkan risiko fibrilasi atrium melalui beberapa jalur, termasuk peningkatan tekanan pengisian, kekacauan pengaturan kanal kalsium, dan disfungsi otonom dan neuroendokrin. Peregangan atrium mengakibatkan aktivasi peregangan arus ion, meningkatkan penyebaran fase refraktor serta perubahan anisotop dan konduksi. Gagal jantung berhubungan dengan peningkatan fibrosis di jaringan intertitial. Peningkatan fibrosis ini memulai konduksi abnormal di atrium. Disregulasi kanal ion kalsium merupakan hal penting pada patofisiologi gagal jantung dan hubungannya dengan fibrilasi atrium. Fibrilasi atrium terjadi kekacauan regulasi metabolisme interseluler kalsium, reseptor ryanodine dan retikulum sarkoplasma $\mathrm{Ca}^{2+}$-ATPase. Gangguan jalur neurohormonal pada gagal jatung melalui peningkatan konsentrasi katekolamin dan angiostensin II. Aktivasi neurohormonal sistem renin angiostensin aldosteron menimbulkan fibrosis pada miokardium melalui peningkatan regulasi jalur TGF-â1. Angiostensin II dan TGF-âl memicu peregangan miosit yang akan menstimulasi deposit kolagen oleh fibroblas. ${ }^{19}$

Fibrilasi atrium dengan kelainan katup jantung (valvular) merupakan fibrilasi atrium yang terjadi akibat kelainan katup terutama stenosis mitral, regurgitasi mitral dan pemakaian katup prostetik. Stenosis mitral berhubungan dengan fibrilasi atrium melalui peningkatan diameter atium kiri. Penyebab fibrilasi atrium valvular di RSUD Arifin Achmad Provinsi Riau paling banyak disebabkan oleh stenosis mitral yaitu $37,2 \%$. Hasil penelitian ini sesuai dengan penelitian Sharma SK dkk (2015) yaitu 48,2\% dan penelitian Majeed I dkk (2009) yaitu $35 \% .{ }^{20,21}$

Daerah katup mitral normalnya berukuran 4-6 $\mathrm{m}^{2}$. Ukuran ini dapat mengecil akibat infeksi, kelainan bawa lahir, degeneratif, tumor dan trombus. Keadaan ini mengakibatkan penyempitan pada daerah katup mitral sehingga terjadi bendungan akibat peningkatan volume darah di atrium kiri. Bendungan darah secara langsung mengakibatkan atrium kiri meregang sebagai kompensasi dari overload darah yang akan dipompa selama fase diastolik. Peningkatan yang terjadi secara kronis mengakibatkan peregangan maksimal dan dilatasi di atrium kiri. Peregangan pada sel miosit dan otot miokardium mengakibatkan gangguan pada konduksi yang akan berdampak pada fibrilasi atrium.Daerah katup mitral kurang dari $1 \mathrm{~cm}^{2}$ pasien baru akan kerumaah sakit akibat mengeluhkan gangguan aktivitas pada saat istirahat. ${ }^{22}$ 


\section{Hubungan antara Angka Kejadian Fibrilasi Atrium dengan Kelainan Katup (valvular) dan tanpa Kelainan Katup Jantung (nonvalvular) dengan diameter atrium kiri}

Hasil penelitian ini didapatkan bahwa tidak ada hubungan antara angka kejadian fibrilasi atrium dengan kelainan katup (valvular) dan tanpa kelainan katup jantung (nonvalvular) dengan diameter arium kiri di RSUD Arifin Achamad Provinsi Riau dengan nilai $p=0,273$. Belum ada penelitian yang membahas mengenai hubungan fibrilasi atrium valvular dan nonvalvular dengan diameter atrium kiri, sehingga penelitian ini tidak dapat perbandingan hasil terhadap penelitian lain.

Penelitian ini menunjukkan insidensi fibrilasi atrium valvular dengan diameter atrium kiri $>40 \mathrm{~mm}$ yaitu 32 pasien $(74,4 \%)$ dan fibrilasi atrium nonvalvular dengan diameter atrium kiri $>40 \mathrm{~mm}$ yaitu 93 pasien $(65,5 \%)$. Hasil penelitian ini sesuai dengan penelitian Rashid MA dkk (2014) yang meneliti tentang persentase fibrilasi atrium nonvalvular atrium kiri yaitu, 144 pasien $(68,56 \%){ }^{23}$ Penelitian ini sesuai dengan penelitian yang dilakukan oleh Havranek S dkk yang meneliti tentang hubungan diameter atrium kiri dengan fibrilasi atrium nonvalvular dan menunjukkan lemahnya hubungan antara diameter atrium kiri dengan fibrilasi atrium nonvalvular. ${ }^{24}$ Penelitian mengenai hubungan kejadian fibrilasi atrium valvular dengan diameter atrium kiri masih belum ada.

Faktor risiko fibrilasi atrium terdiri dari obesitas, merokok, hipertensi, alkohol, hiperlipidemia, infark miokardium, diabetes dan sleep apnea. Faktor risiko kardiovaskular seperti hipertensi, diabetes mellitus, hiperlipidemia, dan infark miokardium mengakibatkan perubahan langsung pada struktur atrium dan terjadi remodelling pada sel-sel otot atrium. Remodelling di atrium dapat terjadi pada sel dan remodelling pada konduksi. Faktor risiko seperti hipertensi dan gagal jantung membuat peregangan pada otot-otot miokardium sebagai kompensasi. Hal ini memicu proses remodelling pada konduksi secara langsung sehingga memicu terjadinya fibrilasi atrium tanpa terjadi remodelling sel atrium terlebih dahulu. Selain remodelling pada konduksi atrium, peregangan akibat faktor risiko ini juga memicu perubahan pada kanal ion kalsium, sistem renin angiostensin aldosteron, endothelin-1, natriuretik peptida, stress inflamasi oksidatif, dan heat shock protein. Peningkatan kalsium intraseluler, sistem renin angiostensin aldosteron, endhotelin-1, penurunan natriuretik peptida, stress inflamasi oksidatif, dan penurunan heat shock protein merupakan faktor yang memicu terjadinya remodelling pada sel-sel otot miokardium. Remodelling sel-sel atrium ini berupa fibrosis, diferensiasi, apoptosis, miolisis hipertrofi, dan dilatasi atrium. Remodelling yang dapat dinilai melalui ekokardiografi adalah hipertrofi dan dilatasi atrium. ${ }^{22}$

Fibrilasi atrium akibat kelainan katup jantung secara langsung mengakibatkan peningkatan tekanan di atrium kiri. Peningkatan tekanan atrium kiri secara terus menerus mengakibatkan terjadi dilatasi atrium yg progresif.Keadaan ini memicu fibrosis dan remodelling elektrofisiologis sehingga memicu munculnya fibrilasi atrium. ${ }^{22}$

\section{KESIMPULAN}

Berdasarkan hasil penelitian yang telah dilakukan dapat diambil kesimpulan bahwa penderita fibrilasi atrium pada laki-laki yaitu 110 pasien $(59,5 \%)$ dan usia penderita fibrilasi atrium bervariasi dan usia paling banyak terjadi pada penelitian ini antara 51-60 tahun yaitu 60 pasien $(32,4 \%)$. Frekuensi fibrilasi atrium tanpa kelainan katup jantung lebih banyak dibandingkan fibrilasi atrium dengan kelainan katup jantung, yaitu 142 pasien (76,8\%). Frekuensi fibrilasi atrium dengan kelainan katup jantung di RSUD Arifin Achmad provinsi Riau yaitu 43 pasien $(23,2 \%)$ dan frekuensi fibrilasi atrium tanpa kelainan katup jantung di RSUD Arifin Achmad provinsi Riau yaitu 142 pasien $(76,8 \%)$. Fibrilasi atrium dengan kelainan katup jantung sebanyak 48 pasien. Penyebab fibrilasi atrium valvular paling banyak disebabkan oleh stenosis mitral yaitu 16 pasien $(37,2 \%)$. Fibrilasi atrium tanpa kelainan katup jantung sebanyak 142 pasien. Penyebab fibrilasi atrium paling banyak disebabkan oleh hipertensi yaitu 59 pasien $(41,5 \%)$.Tidak terdapat hubungan antara diameter atrium kiri terhadap fibrilasi atrium valvular dan nonvalvular di RSUD Arifin Achmad provinsi Riau. 


\section{DAFTAR PUSTAKA}

1. Murphy NF, Simpson CR, Jhund PS, et al. A national survey of the prevalence, incidence, primary care burden and treatment of atrial fibrillation in Scotland. Heart. 2007;93:606-612.

2. Go AS, Hylek EM, Philips KA, Chang Y, Henault LE, Selby JV, et al. Prevalence of diagnosed atrial fibrillation in adults: National implication for rhytm management and stroke prevention: the AnTicoagulation and Risk factors in Atrial Fibrillation (ATRIA) Study. JAMA.2001; 285: 2370-2375

3. Miyasaka Y, Barnes ME, Gersh BJ, Cha SS, Bailey KR, Abhayaratna WP, et al. Secular trends in incidence of atrial fibrillation in Olmsted Country, Minnesota, 1980 to 2000, and implications on the projections for future prevalence, Circulation. 2006;114:119-125

4. Yuniadi Y, Tondas AE, Hanafi DA, Hermato DY, Maharani E, Munawar M, et al. Pedoman tata laksana fibrilasi atrium edisi ketiga. Centra Communications. 2014.

5. Lang RM, Bierig $M$, Devereux RB. Recommendations for chamber quantification. J Am Soc Echocardiogr. 2005 Dec; 18(12):144063.

6. Wang TJ, Larson MG, Levy D, et al. Temporal relations of atrial fibrillation and congestive heart failure and their joint influence on mortality: the Framingham Heart Study. Circulation. 2003; 107:2920-5.

7. January CT, Wann LS, Alpert JS, Calkins H, Cigarroa JE, Cleveland JC Jr, et al. ACC/AHA Task Force Members. 2014 AHA/ ACC/HRS guideline for the management of patients with atrial fibrillation: executive summary: a report of the American College of Cardiology/ American Heart Association Task Force on practice guidelines and the Heart Rhythm Society. Circulation. 2014;130:2071-2104.

8. Camm AJ, Lip GYH, De Caterina R, Savelieva I, Atar D, Hohnloser SH, Hindricks G, Kirchhof P. 2012 focused update of the ESC Guidelines for the management of atrial fibrillation: an update of the 2010 ESC Guidelines for the management of atrial fibrillation. Developed with the special contribution of the European Heart Rhythm Association. Eur Heart J. 2012; 33:2719-2747.

9. Philippart R, Brunet-Bernard A, Clementy N, Bourguignon T, Mirza A, Babuty D, Angoulvant D, Lip GYH, Fauchier L. Prognostic value of CHA2DS2-VASc score in patients with "nonvalvular atrial fibrillation' and valvular heart disease: the Loire Valley Atrial Fibrillation Project. Eur Heart J 2015;36:1822-1830.

10.Berisso MZ, Lercari F, Carazza T, Dommenicucci S. Epidemiology of atrial fibrillation: European perspective. Clinical Epidemiology. 2014: 6: 213-220

11. Chugh SS, Havmoeller R, Narayanan K, Singh D, Rienstra M, Benjamin EJ et al. Worldwide epidemiology of atrial fibrillation a global burden of disease 2010 study. Circulation. 2014; 129:837-847.

12.Friberg L, Bergfeldt L. Atrial fibrillation prevalence revisited. Journal Internal Medicine. 2013: 274; 461-468.

13.Liu XK, Jahangir A, Terzic A, Gersh BJ, Hammill SC, Shen WK. Ageand sex-related atrial electrophysiologic and structural changes. Am JCardiol. 2004;94:373-375.

14. Ayed SD, Ayed S, Atig R, Tilouche N, Ali HBS, Gharbi R, et al. New onset of atrial fibrillation in a medical ICU: Prevalence and risk factors. Scientific research. 2012: 3; 582-586.

15.Rao DV, Reddy MR, Srikanth K, Prakash RK, Prasad AS, Prasad GS. To study the prevalence and clinical profile of chronic atrial fibrillation inhospitalized patients. Nitte University Journal of Health Science. 2014; 4.

16.Badan Pusat Statistik. Statistik Susilo D, Chamami A, Handayani NB, editors. Subdirektorat Statistik Pendidikan dan Kesejahteraan Sosial. Jakarta: Badan Pusat Statistik; 2015. 19-24.

17. Nabar A, Pathan I. Pathophysiology of atrial fibrillation current concepts. Supplement to journal of the Association of Physicians of India. 2016. 
18.Ertas F, Kaya H, Kaya Z, Bulur S, Kose N, Gul M. Epidemiology of atrial fibrillation in Turkey: preliminary result of the multiceenter after study. Turkish Society of Cardiology. 2013; 41(2):99104.

19.Lubitz SA, Benjamin EJ, Ellinor PT. Atrial fibrillation in congestion heart failure. National Institute of Health. 2010; 6(2):187-200.

20.Sharma SK, Verma SH. A clinical evaluation of atrial fibrillation in rheumatic heart disease. Journal of the Association physicians of India.2015;(3).

21.Majjed I, Shafi SS, Abid RA, Iqbal T, Adzhar M. Correlation of Left Atrial Size with Atrial Fibrillation in Patients of Mitral Stenosis Undergoing Percutaneous Transluminal Mitral Commissurotomy. Associate Professor of Cardiology. 2009;(1).
22.Naema KP, Raippur. Pathophysiology of mitral valve stenosis. Departement of Anasthesiology. 2015;(1)25-27.

23. Rashid MA, Valait A, Hussain A, Naveed T, Noeman A, Hameed S. Left atrial size in nonvalvular atrial fibrillation: Percentage increase in diagnosis of left atrial size by m-mode versus prolate ellipse volume method. The Journal of cardiovascular Disease. 2014; (12)101-105.

24.Havranek S, Bulkova V, Fiala M, Sknouril L, Chovancik J, Simek J, Wichterle D. Poor relationship between left atrial diameter and volume in patient with atrial fibrillation. Elsevier. 2012. 